\title{
SUPPLEMENTATION OF NUTRIENTS FOR TABLE BEETS BY IRRIGATION WITH TREATED DAIRY EFFLUENT
}

Doi:http://dx.doi.org/10.1590/1809-4430-Eng.Agric.v37n6p1137-1147/2017

\section{TAMARA M. GOMES ${ }^{1 *}$, FABRÍCIO ROSSI ${ }^{2}$, GIOVANA TOMMASO ${ }^{2}$, ROGERS RIBEIRO ${ }^{2}$, MARTA M. KUSHIDA ${ }^{2}$, MICHAEL JAMES STABLEIN ${ }^{3}$}

${ }^{1 *}$ Corresponding author. School of Animal Science and Food Engineering (FZEA) - University of São Paulo, Pirassununga - SP, Brazil. E-mail: tamaragomes@usp.br

\begin{abstract}
This study was conducted to evaluate the nutritional status of table beet plants cultivated in a greenhouse irrigated with treated dairy effluent at different irrigation depths. The experimental design used was a randomized block in a $3 \times 3+1$ factorial arrangement with four replications and conducted in a greenhouse. The treatments consisted of three types of water sources and three irrigation depths applied by drip irrigation: anaerobic effluent; anaerobic/aerobic effluent; tap water, and irrigation for replenishment 50; 100 and $150 \%$ of the crop evapotranspiration (ETc). All these treatments were applied in combination with $50 \%$ of the recommended nitrogen fertilization for the table beet cultivation. A control treatment was irrigated with tap water with irrigation depth equal to $100 \%$ ETc and received the complete dose (100\%) of mineral nitrogen fertilizer. Table beet seedlings were arranged in 40 fiberglass boxes with a base area of $1 \mathrm{~m}^{2}$. Table beets were harvested 72 days after transplanting (DAT) when the leaves and roots were analyzed. Irrigation with wastewater promoted appropriate levels of macronutrients, distributed between the leaves and roots. The sodium was increased significantly in the leaves and roots of table beets in effluent treatments at increasing irrigation depths, which was antagonistic to the absorption of potassium.
\end{abstract}

KEYWORDS: water reuse, Beta vulgaris, anaerobic and aerobic system, drip, nutritional status.

\section{INTRODUCTION}

The increase in food consumption coupled with the stagnation of the area available for agricultural crops intensifies the use of more productive systems to optimize natural resource and land use.

The processing of animal and vegetable products from agroindustries, mainly food using fermentative processes, generates liquid residues rich in organic matter, nutrients, and salts, and even after treatment, they still present potential for pollution to the water bodies, mainly due to the presence of nitrogen and phosphorus (Karadag et al., 2015). It is important to note that most dairy plants are small and medium-sized with financial difficulties to keep specialized personnel and are thus unable to implement technological innovations that allow environmentally appropriate disposal of these waters (Saléh, et al., 2009). In cases where dairy plants do not remove whey from the effluent, they produce four times the volume of milk processed (Carvalho et al., 2013).

Irrigation with wastewater of organic origin is an alternative to replace quality water, allows the maintenance of soil moisture, acts as source of nutrients, and prevents the risk of contamination of water resources. Regarding the nutritional development of plants, the effluent presented agronomically desirable characteristics such as the presence of nitrogen $(\mathrm{N})$, phosphorus $(\mathrm{P})$, and potassium (K) macronutrients (Bame et al., 2014; Grundmann \& Maab, 2017, Pereira et al., 2011; Singh et al., 2010; Bourazanis et al., 2016)

Regarding implications for agricultural reuse, several aspects have been widely evaluated and discussed. One of the relevant aspects, of a sanitary nature, is related to the recommended microbiological guidelines for the use of sewage in agriculture (Pedrero et al., 2012; US EPA,

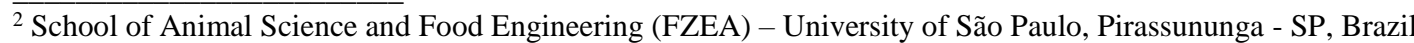

${ }^{3}$ University of Illinois Urbana-Champaign, Urbana, IL, USA.

Received in: 3-24-2017

Accepted in: 8-21-2017
} 
2012), where concerns are concentrated on the health of the farmer and consumers of agricultural products. Other environmental aspects refer to the possible accumulation of heavy metals and toxic elements in soils and plants, the contamination of groundwater by these substances and nitrate (Elgallal et al., 2016; Leal et al., 2009), increase in soil salinity and sodicity (Matsumoto et al., 2012; Ganjegunte et al., 2017; Assouline \& Narkis, 2011; Muyen et al., 2011) changes in its physical properties (Abegunrin et al., 2016; Bonini et al., 2014; Levy et al., 2014), and unbalanced supply of nutrients to plants (Blum, 2011; Pereira et al., 2011).

Table beet consumption, as part of a healthy diet, is intensified in the summer, a time of low supply by producers due to high temperatures and precipitation. During the last ten years in Brazil, an increase in demand for consumption and processing of this fresh tuberous crop in the food industries has been observed. Currently, table beet is one of the 17 most important vegetables propagated in Brazil (Tivelli et al., 2011). According to AGRIANUAL (2016), the commercial volume of table beets for the Society of Warehouses and General Warehouses of São Paulo (CEAGESP) was $16,682.00$ tons in 2016. The cultivation in a protected environment is an important alternative to guarantee both production in the off season and financial return. The guarantee of production when irrigated with water with a certain salt content, classified as moderately tolerant (Ayers \& Westcot, 1999), makes table beet a favorable crop for cultivation with wastewater.

The objective of the present study was to evaluate the nutritional status of table beet plants irrigated with different water sources (treated dairy effluents) and irrigation depths in protected cultivation.

\section{MATERIAL AND METHODS}

The experiment was conducted in a greenhouse $\left(210 \mathrm{~m}^{2}\right)$ of arc type at the University of São Paulo Animal Science and Food Engineering campus located in the city of Pirassununga / SP, Brazil, latitude $21^{\circ} 59^{\prime} \mathrm{S}$, longitude $47^{\circ} 26^{\prime} \mathrm{W}$, and altitude of $634 \mathrm{~m}$. The climate is subtropical, type CWa, with dry winters and hot and rainy summers, according to the Köppen classification (Oliveira \& Prado, 1984). The minimum and maximum values for temperature and relative humidity inside the greenhouse during the experiment interval are shown in Figure 1.
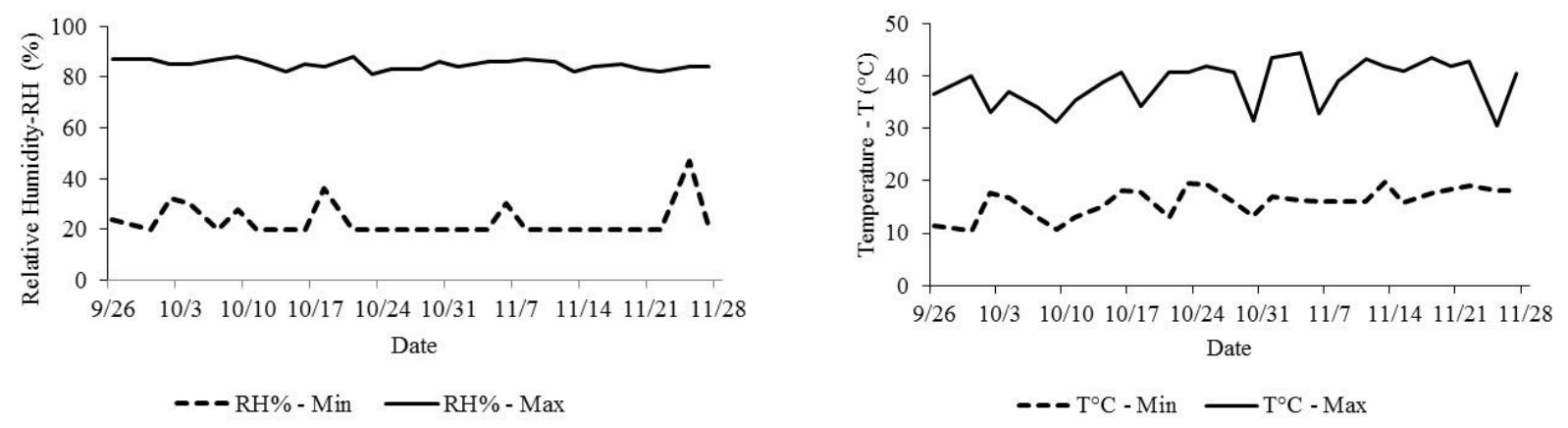

FIGURE 1. Minimum (Min) and maximum (Max) relative humidity $(\%)$ and temperature $\left({ }^{\circ} \mathrm{C}\right)$ values between 9/26/2013 and 11/27/2013.

The experimental design used randomized blocks in a $3 \times 3+1$ factorial scheme with four replicates. The treatments were from three sources of water: (1) anaerobic effluent - ANE, treated by a sequential anaerobic batch reactor with a biofilm; (2) aerobic effluent - AE, fixed bed anaerobic / aerobic combined reactor; and (3) tap water - TW, treated by direct filtration followed by chlorination. Three irrigation depths, W1, W2, and W3, with 50\%, 100\%, and $150 \%$ replacement of crop evapotranspiration (ETc) estimation, respectively, were used. The treatments were applied in combination with $50 \%$ of the mineral nitrogen fertilization recommended for table beets, in addition to the control table beet with $100 \%$ of the need for mineral nitrogen fertilization and $100 \%$ of ETc-W2. 
Table beet seedlings, 'Cabernet' hybrid, were transplanted on 09/16/2013 and arranged in fiberglass boxes with a base area of $1 \mathrm{~m}^{2}$ and free depth of $40 \mathrm{~cm}$, totaling 40 experimental plots. Each plot received 24 table beet seedlings in 4 rows spaced $0.2 \mathrm{~m}$ and $0.15 \mathrm{~m}$ between plants. Only the two central lines were considered for evaluation.

Regarding the applied waters, the effluents were filtered by geotextile fabric and disinfected by ultraviolet lamps. During the experiment, the effluent and TW samples were collected for analysis at the points before the irrigation system with biweekly frequency, totaling five samplings. Conditioning and sampling were performed according to the National Guide for Collection and Preservation of Water Samples (CETESB/ANA, 2011) and analyzed according to APHA, AWWA, WEF (2012). The parameters analyzed were: electrical conductivity (EC), pH, total Kjeldahl nitrogen $(\mathrm{N}-\mathrm{TKN}), \mathrm{N}-\mathrm{NH}_{4}^{+}, \mathrm{N}-\mathrm{NO}_{3}^{-}, \mathrm{N}-\mathrm{NO}_{2}^{-}, \mathrm{P}_{-} \mathrm{PO}_{4}^{-}, \mathrm{Na}^{+}, \mathrm{Ca}^{+2}, \mathrm{Mg}^{+2}, \mathrm{~K}^{+}$, alkalinity, and total volatile acids. The sodium adsorption ratio (SAR) was determined according the method by to Ayers \& Westcot (1999) (Table 1). Before and after the reactors (ANE and AE), the chemical oxygen demand (COD) was determined. The raw and filtered COD at the entrance of the dairy effluent treatment plant prior to treatment was $1894.03 \pm 633.48 \mathrm{mg} \mathrm{L}^{-1}$ and $1429.46 \pm 583.60 \mathrm{mg}$ $\mathrm{L}^{-1}$, respectively, and they were reduced by $90.81 \%$ in the anaerobic system and $96.77 \%$ in the aerobic system after treatment.

TABLE 1. Mean and standard deviation of chemical parameters for treated dairy effluents and tap water.

\begin{tabular}{|c|c|c|c|}
\hline Parameter & TW & $\mathrm{AE}$ & ANE \\
\hline$\overline{\mathrm{N}-\mathrm{TKN}}\left(\mathrm{mg} \mathrm{L}^{-1}\right)$ & ND & $1.39 \pm 2.77$ & $42.24 \pm 1.77$ \\
\hline $\mathrm{N}-\mathrm{NH}_{4}{ }^{+}\left(\mathrm{mg} \mathrm{L}^{-1}\right)$ & ND & $0.31 \pm 0.62$ & $16.29 \pm 9.05$ \\
\hline $\mathrm{N}-\mathrm{NO}_{3}^{-}\left(\mathrm{mg} \mathrm{L}^{-1}\right)$ & $0.20 \pm 0.04$ & $10.60 \pm 4.51$ & $0.37 \pm 0.44$ \\
\hline $\mathrm{N}-\mathrm{NO}_{2}^{-}\left(\mathrm{mg} \mathrm{L}^{-1}\right)$ & $0.20 \pm 0.40$ & $4.50 \pm 1.73$ & $0.09 \pm 0.05$ \\
\hline $\mathrm{P}_{-} \mathrm{PO}_{4}^{-}\left(\mathrm{mg} \mathrm{L}^{-1}\right)$ & ND & $0.80 \pm 0.16$ & $1.30 \pm 0.23$ \\
\hline $\mathrm{Ca}^{+2}\left(\mathrm{mg} \mathrm{L}^{-1}\right)$ & $3.27 \pm 0.97$ & $42.84 \pm 22.34$ & $45.43 \pm 14.24$ \\
\hline $\mathrm{Mg}^{+2}\left(\mathrm{mg} \mathrm{L}^{-1}\right)$ & $1.68 \pm 1.02$ & $51.44 \pm 35.79$ & $52.79 \pm 53.09$ \\
\hline $\mathrm{Na}^{+}\left(\mathrm{mg} \mathrm{L}^{-1}\right)$ & ND & $50.25 \pm 13.05$ & $69.80 \pm 18.43$ \\
\hline $\mathrm{K}^{+}\left(\mathrm{mg} \mathrm{L}^{-1}\right)$ & $0.50 \pm 0.14$ & $112.50 \pm 79.23$ & $56.77 \pm 70.36$ \\
\hline $\mathrm{Fe}\left(\mathrm{mg} \mathrm{L}^{-1}\right)$ & $0.20 \pm 0.14$ & $0.06 \pm 003$ & $0.17 \pm 0.22$ \\
\hline $\operatorname{Mn}\left(\mathrm{mg} \mathrm{L}^{-1}\right)$ & $0.002 \pm 0.000$ & $0.006 \pm 0.006$ & $0.014 \pm 0.008$ \\
\hline $\operatorname{SAR}\left(\mathrm{mmol}_{\mathrm{c}} \mathrm{L}^{-1}\right)^{0.5}$ & - & $1.32 \pm 0.32$ & $1.86 \pm 0.49$ \\
\hline $\mathrm{EC}\left(\mathrm{dS} \mathrm{m} \mathrm{m}^{-1}\right)$ & $0.03 \pm 0.00$ & $1.15 \pm 0.53$ & $2.05 \pm 0.69$ \\
\hline $\mathrm{Ph}$ & $6.97 \pm 0.32$ & $8.27 \pm 0.20$ & $7.92 \pm 0.16$ \\
\hline Alkalinity $\left(\mathrm{mg} \mathrm{L}^{-1}\right)$ & $19.75 \pm 7.80$ & $682.12 \pm 225.65$ & $1.256 .53 \pm 306.27$ \\
\hline $\operatorname{TVA}\left(\mathrm{mg} \mathrm{L}^{-1}\right)$ & $10.22 \pm 1.45$ & $25.61 \pm 5.29$ & $66.82 \pm 42.82$ \\
\hline
\end{tabular}

$\mathrm{TW}=$ Tap water; $\mathrm{AE}=$ Aerobic effluent; $\mathrm{ANE}=$ Anaerobic effluent; $\mathrm{TKN}=$ Total Kjeldahl Nitrogen, $\mathrm{SAR}=$ Sodium Adsorption Ratio; $\mathrm{EC}=$ Electrical Conductivity; TVA= Total Volatile Acids; ND= Not Detected.

Irrigation was performed using a $2.4 \mathrm{~L} \mathrm{~h}^{-1}$ flow drip system, spaced at $0.20 \mathrm{~m}$ with one irrigation line for every two crop lines.

Irrigation management was based on the restoration of the crop evapotranspiration estimation (ETc) by the evaporation of the reduced class A tank, installed in the central part of the greenhouse. The culture coefficients $(\mathrm{Kc})$ used was proposed by Marouelli et al. (2008) for the different stages of development. The reduced tank correction coefficient (Kp) proposed for the environment was 1 , as recommended by Prados (1986) and cited by Farias et al. (1994). The irrigation frequency was every two days beginning on 09/25/2013 with the application of the different depths (W1 $=50 \%$, $\mathrm{W} 2=100 \%$, and $\mathrm{W} 3=150 \%$ ). Soil moisture was monitored weekly in each experimental plot by the gravimetric method. The total irrigation depths applied to the three water types (ANE, AE, and TW) were TW - 187.25; 356.75; $573.5 \mathrm{~mm}$ for W1, W2, and W3, respectively; ANE - 148.00; $238.50 ; 354.75 \mathrm{~mm}$ for $\mathrm{W} 1, \mathrm{~W} 2$, and $\mathrm{W} 3$, respectively; and $\mathrm{AE}=162.00 ; 260.00 ; 362.25 \mathrm{~mm}$ for $\mathrm{W} 1, \mathrm{~W} 2$, and $\mathrm{W} 3$, respectively.

The soil used to fill the experimental plots, being predominant in the region, was classified as Red Latosol, according to EMBRAPA (1999). A composite sample was taken and sent for analysis in the Laboratory of Agricultural Sciences/FZEA Soils/USP (Table 2). 
TABLE 2. Soil analysis for experimental plots.

\begin{tabular}{|c|c|c|c|c|c|c|c|c|}
\hline $\begin{array}{l}\mathrm{pH} \\
\left(\mathrm{CaCl}_{2}\right)\end{array}$ & \multicolumn{2}{|c|}{$\begin{array}{l}\mathrm{P} \\
\text { (res) } \\
\left(\mathrm{mg} \mathrm{dm} \mathrm{dm}^{-3}\right) \\
\end{array}$} & \multicolumn{2}{|c|}{ 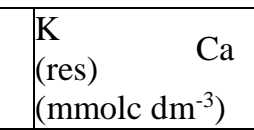 } & \multirow{2}{*}{$\begin{array}{c}\mathrm{Mg} \\
10 \\
\end{array}$} & \multirow{2}{*}{$\begin{array}{l}\mathrm{H}+\mathrm{Al} \\
20 \\
\end{array}$} & \multirow{2}{*}{\begin{tabular}{|l} 
O.M. \\
$\left(\mathrm{g} \mathrm{kg}^{-}\right.$
\end{tabular}} & \multirow{2}{*}{$\begin{array}{l}\text { T.C. } \\
12,9 \\
\end{array}$} \\
\hline 6.0 & 6 & 31 & 1,7 & 30 & & & & \\
\hline \multicolumn{9}{|l|}{ Continued } \\
\hline $\begin{array}{l}\mathrm{BS} \\
\left(\mathrm{mmolc} \cdot \mathrm{dm}^{-3}\right)\end{array}$ & CEC & $\begin{array}{l}\mathrm{V} \\
(\%)\end{array}$ & $\begin{array}{l}\mathrm{B} \\
(\mathrm{mg}\end{array}$ & $\mathrm{Cu}$ & $\mathrm{Fe}$ & $\mathrm{Mn}$ & $\mathrm{Zn}$ & \\
\hline 42 & 62 & 67 & 0.18 & 1.5 & 7 & 5.1 & 1.6 & \\
\hline \multicolumn{9}{|l|}{ Continued } \\
\hline $\begin{array}{l}\text { Total Sand } \\
\text { Texture }\left(\mathrm{g} \mathrm{dm}^{-3}\right)\end{array}$ & Clay & Silt & \multicolumn{6}{|c|}{ Texture Classification } \\
\hline 640 & 341 & 19 & Mea & & & & & \\
\hline
\end{tabular}

BS=Base Sum; O.M.=Organic Material; T.C.=Total Carbon; CEC=Cation Exchange Capacity; V=Saturation per base.

The initial result of the soil analysis (Table 2) defined the fertilization doses for table beet cultivation, as suggested by Raij et al. (1996), with $360 \mathrm{~kg} \mathrm{ha}^{-1}$ of $\mathrm{P}_{2} \mathrm{O}_{5}, 180 \mathrm{~kg} \mathrm{ha}^{-1}$ of $\mathrm{K}_{2} \mathrm{O}, 2 \mathrm{~kg}$ $\mathrm{ha}^{-1} \mathrm{H}_{3} \mathrm{BO}_{3}$, and $20 \mathrm{~kg} \mathrm{ha}^{-1}$ of organic matter (commercial preparation provided by Vida Verde, state of São Paulo, Brazil). It was decided to perform differentiated fertilization by depth, concentrating the fertilization of macro and micronutrients in the top $0.2 \mathrm{~m}$. In the total volume of the plot, $351 \mathrm{~L}$, the proportion of two parts of soil was mixed for one part of fine sand, in addition to limestone with $\mathrm{RTNP}^{1}=71 \%$, in order to raise $\mathrm{V} \%$ to $72 \%$. Three nitrogen fertilizations were carried out on days 07,17 , and 31 of October 2013 in the form of ammonium nitrate with 50\% of the dose of $120 \mathrm{~kg}$ of nitrogen per hectare, as recommended by Raij et al. (1996) for table beets, in all treatments except for the control, which received $100 \%$ of the dose $\left(120 \mathrm{~kg}_{\text {of N ha}}{ }^{-1}\right)$.

Harvesting occurred on the 11/27/2013, seventy-one days after planting the seedlings, for leaf and root samples to be washed at that time with water and hydrochloric acid solution at a dilution of $0.1 \%$ to remove impurities, and then, they were dried in an oven with forced circulation at $65^{\circ} \mathrm{C}$. Subsequently, the samples were processed in a mill and sent for nutritional diagnosis analysis, in accordance with Malavolta et al. (1997), by the Laboratory of Agricultural Sciences/FZEA Soils/USP. After sampling, soil samples were taken in each experimental plot at depths of 0-10 cm and $10-20 \mathrm{~cm}$, and the samples were submitted for chemical fertility analysis, according to the methodology described in Raij et al. (2001), to determine sodium for calculation of the percentage of exchangeable sodium in the soil (Laboratory of Agricultural Sciences/FZEA Soils/USP).

The data were submitted to analysis of variance. For the situations in which there were significant differences, the averages were compared by the Tukey test with a significance level of $5 \%$. For the comparisons between the control and the treatments, the Dunnett test was applied with a significance level of 5\%. The software used was SISVAR 5.3 (Ferreira, 2011).

\section{RESULTS AND DISCUSSION}

The production of table beet roots was influenced by the use of treated dairy effluents and the applied irrigation depths. The development of plants was favored when irrigated with ANE and AE. Irrigation with effluent treated with anaerobic system resulted in better yields in all irrigation depths compared to other treatments (AE and TW) (Gomes et al., 2015).

The results of soil chemical analysis after table beet cultivation are presented in Table 3 . By statistical analysis, no difference was observed between the studied soil layers, $0-10 \mathrm{~cm}$ and 10-20 $\mathrm{cm}$.

\footnotetext{
${ }^{1}$ RELATIVE TOTAL NEUTRALIZATION POWER
} 
TABLE 3. Soil chemical analysis after table beet cultivation.

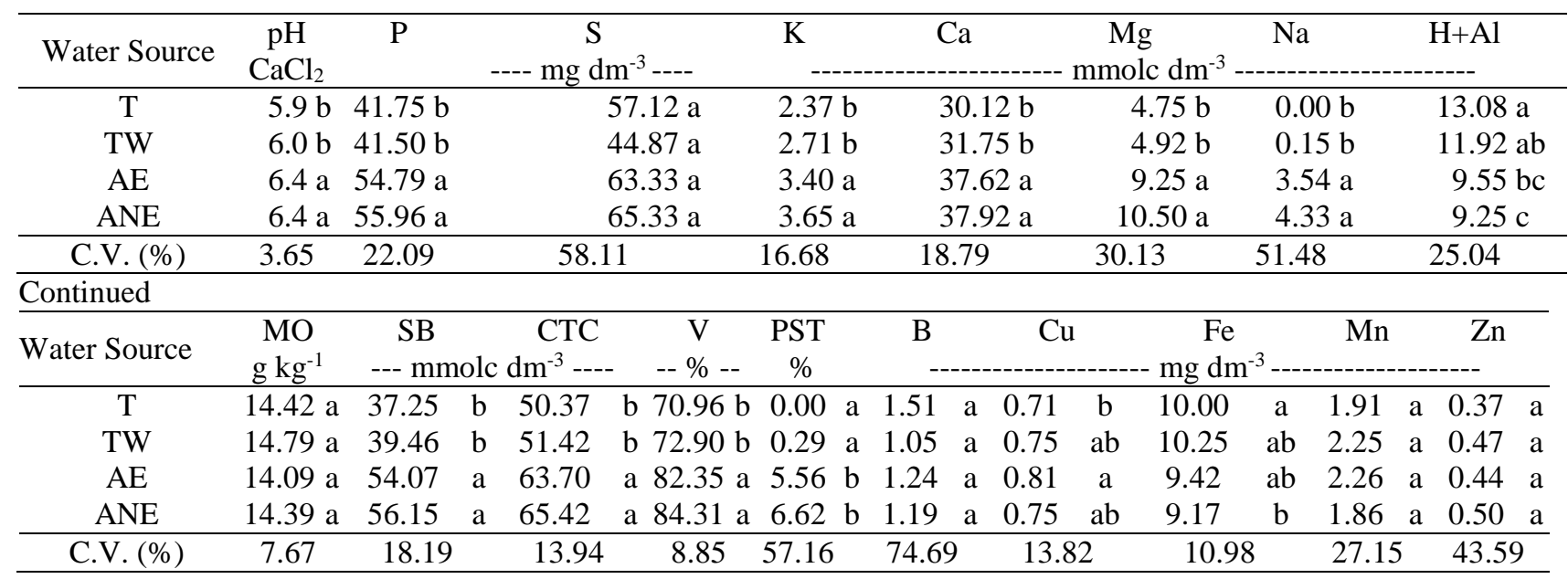

$\mathrm{T}=$ control: $100 \%$ replacement of crop evapotranspiration (ETc) with tap water and $100 \%$ nitrogen fertilization recommended for the crop; $\mathrm{TW}=$ tap water, $50 \%$ of the nitrogen fertilization recommended for the crop; $\mathrm{AE}=$ dairy effluent treated by aerobic system, $50 \%$ of nitrogen fertilization recommended for the crop; ANE = dairy effluent treated by anaerobic system, 50\% of nitrogen fertilization recommended for the crop. Means followed by different letters differed by the Tukey test $(\mathrm{p}<0.05)$.

In the soil, there was no interaction between irrigation depths and water sources; however, the latter factor altered the chemical properties of the soil. Effluent treatments (AE and ANE) significantly increased $\mathrm{pH}$, phosphorus, potassium, calcium, and magnesium values, which resulted in higher values of base sum, cation exchange capacity, and V\%. The micronutrients were not altered by the applied treatments (Table 3). Several authors (Prazeres et al., 2014; Herpin et al. (2007); Gomes et al., 2009; Becerra-Castro et al., 2015; Azevedo \& Oliveira, 2005; Pereira et al., 2011) that have been working with crops irrigated with treated effluents of organic origin, mainly domestic sewage, also obtained similar results for the presence of macronutrients in the soil and a decrease in soil acidity, satisfactory in tropical soils. The sodium values and the percentage of exchangeable sodium in the soil (Table 3) were also higher in treated dairy effluents. The values observed indicate soil sodification potential and are at the limit $(6 \%)$ recommended by the environmental agency of the State of São Paulo, CETESB (2006), as a premise for the application of effluents in agriculture. Research on wastewater of animal origin showed an increase in the percentage of dispersed clay by high salt application (Condé et al., 2013; Erthal et al., 2010). Prazeres et al. (2014) evaluated the soil chemical properties in the production of tomatoes irrigated with pretreated and diluted effluent from the cheese industry at different levels of salinity and verified a linear increase in soil conductivity but also achieved increases in productivity.

Tables 4, 5, 6, and 7 present the macronutrient and micronutrient contents in the leaves and roots of table beet plants. There was an interaction between the treatments (water source and irrigation depths) only for $\mathrm{N}$ and $\mathrm{P}$ in the leaves and $\mathrm{Na}$ in the roots (Table 4 and 6). In the case of sodium, the values increased with greater irrigation depths in the treatments with effluent. Nitrogen leaf contents were inadequate in all treatments, as values were below those suggested by the literature (Trani et al., 1997), except for the AE treatment in W2 that was superior to the control. The form of nitrogen species may influence results of plant absorption. In the present study, the effluent treated by anaerobic system (ANE) presented values of $0.46 \mathrm{mg} \mathrm{L}^{-1}$ and $16.29 \mathrm{mg} \mathrm{L}^{-1}$ for the nitrate and ammoniacal forms, respectively, and for the anaerobic treatment followed by aerobic treatment (AE), the order of magnitude was inverse, being $15.10 \mathrm{mg} \mathrm{L}^{-1}$ and $0.31 \mathrm{mg} \mathrm{L}^{-1}$ for the nitrate and ammoniacal forms, respectively (Table 1). The high concentration of $\mathrm{N}_{-} \mathrm{NH}_{4}^{+}$in the soil solution under certain conditions can be toxic to the plant, competing with the absorption of other cations while the plant needs to maintain the electroneutrality (Britto \& Kronzucker, 2002; Burgarín et al., 1998). In the roots, however, the nitrogen content for anaerobic effluent was similar to the control. For the leaves, phosphorus content was reduced in the treatments with effluent when applied to the smallest irrigation depth, but the contents maintained normal in the root. Herpin et al. (2007), after three years of coffee cultivation with treated domestic sewage, found a reduction in the levels of phosphorus and nitrogen to deficient levels. Pereira et al. (2011) evaluated the impact of 
anaerobic treated effluent treatment on the soil-plant system in citrus plants under tropical conditions, and they found a reduction in $\mathrm{P}$ levels in the plant, associated with nutritional imbalance due to excess sodium and sulfur. For the other nutrients, all the appropriate values were reached, except for the micronutrient $\mathrm{Zn}$ (Table 3). The effects of the different water sources applied by irrigation were present for $\mathrm{K}$ and $\mathrm{Ca}$ in the leaf and $\mathrm{N}, \mathrm{P}, \mathrm{K}, \mathrm{Ca}$, and $\mathrm{Mg}$ in the root. Sodium was significantly increased throughout the plant in effluent treatments. Several authors performing research on crops that received irrigation with increasing doses of salts obtained linear reductions in production because of the absorption of the sodium (Oliveira et al., 2011; Nobre et al., 2013; Andrade et al., 2016). Potassium, both in the leaves and roots, had antagonistic behavior on sodium contents that were decreased in AE and ANE, which was also observed by Pereira et al. (2011) for citrus leaves. According to Epstein \& Bloom (2005), the reduction in potassium content in plants irrigated with organic wastewater may be related to: (i) decreased availability of potassium in the soil due to higher leaching by addition of sodium, which partially replaced potassium in colloids from the soil; (ii) antagonistic effect of high levels of $\mathrm{N}_{-} \mathrm{NH}_{4}^{+}$in the effluent; and (iii) high sodium concentration in the soil solution, which inhibits the passive absorption of potassium through the protein pathways. Calcium was significantly higher, both in the leaf and root for treatments irrigated with tap water supply. Magnesium was higher in the root for treated effluents. The micronutrients, in general for the plant, were not altered by the treatments with the exception of B and $\mathrm{Mn}$ in the leaf and $\mathrm{Mn}$ in the root, which were reduced in the treatments with dairy effluents.

Regarding the nutrients extracted by table beet plants, considering tons per hectare of roots and leaves, the quantities were in the range presented by Tivelli et al. (2011) $\left(\mathrm{N}=78 \mathrm{~kg} \mathrm{ha}^{-1}, \mathrm{~K}=83\right.$ $\mathrm{kg} \mathrm{ha}^{-1}, \mathrm{Ca}=20 \mathrm{~kg} \mathrm{ha}^{-1}$, and $\left.\mathrm{Mg}=27 \mathrm{~kg} \mathrm{ha}^{-1}\right)$ for all treatments except $\mathrm{P}\left(18 \mathrm{~kg} \mathrm{ha}^{-1}\right)$, which was only achieved in the greater irrigation depths with ANE.

TABLE 4. Irrigation depth and water source for nitrogen and phosphorus contents in table beet leaf.

\begin{tabular}{lllll}
\hline & Irrigation Depth & & \\
Water Source & W1 & W2 & W3 & Trani et al. (1997) \\
\hline & Nitrogen $\left(\mathrm{g} \mathrm{kg}^{-1}\right)$ & & \\
TW & $23.05 \mathrm{Aa}$ & $21.72 \mathrm{Ab}$ & $24.62 \mathrm{Aa}$ & \\
AE & $22.62 \mathrm{Ba}$ & $30.73 \mathrm{Aa} \#$ & $2177 \mathrm{Ba}$ & $30-50$ \\
ANE & $26.22 \mathrm{Aa}$ & $26.82 \mathrm{Aab}$ & $23.72 \mathrm{Aa}$ & \\
T & & 24.12 & & \\
C.V. & 13.29 & & \\
& Phosphorous $\left(\mathrm{g} \mathrm{kg}^{-1}\right)$ & & \\
TW & $2.97 \mathrm{Aa}$ & $2.20 \mathrm{ABab}$ & $2.05 \mathrm{Ba}$ & \\
AE & $1.82 \mathrm{Ab}$ & $2.20 \mathrm{Aab}$ & $1.50 \mathrm{Aa} \#$ & $2-4$ \\
ANE & $1.62 \mathrm{Ab \#}$ & $1.60 \mathrm{Ab \#}$ & $2.10 \mathrm{Aa}$ & \\
T & & 3.05 & & \\
C.V. & 22.46 & & & \\
\hline
\end{tabular}

Equivalent upper or lower case letters in rows and columns, respectively, do not differ statistically by the Tukey test (p <0.05). TW = tap water; $\mathrm{AE}=$ aerobic effluent; $\mathrm{ANE}=$ anaerobic effluent; W1 $=50 \%$ of crop evapotranspiration $(\mathrm{ETc}) ; \mathrm{W} 2=100 \%$ of ETc; W3 = $150 \%$ of ETc; C.V. = coefficient of variation. \# Differs from the control by the Dunnett test $(\mathrm{p}<0.05)$. 
TABLE 5. Macro and micronutrient contents in table beet leaf.

\begin{tabular}{|c|c|c|c|c|c|}
\hline \multirow{3}{*}{ Water Source } & $\mathrm{K}$ & $\mathrm{Na}$ & $\mathrm{Ca}$ & $\mathrm{Mg}$ & $S$ \\
\hline & & & $\mathrm{g} \mathrm{kg}^{-1}$ & & \\
\hline & $20-40 *$ & - & $25-35^{*}$ & $3-8^{*}$ & $2-4 *$ \\
\hline $\mathrm{TW}$ & $47.82 \mathrm{a}$ & $135.00 \mathrm{~b}$ & $86.48 \mathrm{a}$ & $35.67 \mathrm{a}$ & $3.36 \mathrm{a}$ \\
\hline $\mathrm{AE}$ & $31.60 \mathrm{bc}$ & $400.28 \mathrm{a}$ & $44.88 b$ & $24.71 \mathrm{a}$ & $3.12 \mathrm{a}$ \\
\hline ANE & $25.30 \mathrm{c}$ & $413.33 a$ & $40.59 b$ & $35.77 \mathrm{a}$ & $2.95 \mathrm{a}$ \\
\hline $\mathrm{T}$ & $38.72 b$ & $107.50 \mathrm{~b}$ & $66.60 \mathrm{ab}$ & $27.93 \mathrm{a}$ & $3.50 \mathrm{a}$ \\
\hline C.V. & 15.74 & 11.16 & 33.86 & 32.31 & 19.22 \\
\hline \multicolumn{6}{|l|}{ Continued } \\
\hline \multirow{3}{*}{ Water Source } & B & $\mathrm{Cu}$ & $\mathrm{Fe}$ & Mn & $\mathrm{Z}$ \\
\hline & & & $\mathrm{mg} \mathrm{kg}{ }^{-1}--$ & & \\
\hline & $40-80 *$ & $5-15^{*}$ & $70-200 *$ & $70-200 *$ & $20-100 *$ \\
\hline TW & $303.17 \mathrm{a}$ & $6.84 a$ & $345.43 a$ & $404.09 a$ & $15.02 \mathrm{a}$ \\
\hline $\mathrm{AE}$ & $177.17 \mathrm{~b}$ & $6.87 \mathrm{a}$ & $302.39 a$ & $226.90 b$ & $14.39 \mathrm{a}$ \\
\hline ANE & $185.25 b$ & $8.19 \mathrm{a}$ & $282.14 \mathrm{a}$ & $195.56 b$ & $14.00 \mathrm{a}$ \\
\hline $\mathrm{T}$ & $351.02 \mathrm{a}$ & $8.57 \mathrm{a}$ & $391.55 \mathrm{a}$ & $474.75 a$ & $16.80 \mathrm{a}$ \\
\hline C.V. & 15.74 & 26.03 & 34.07 & 24.40 & 19.50 \\
\hline
\end{tabular}

* Adequate contents, Trani et. al., 2007. Equal lowercase letters in the columns do not differ statistically by the Tukey test (p <0.05). $\mathrm{TW}=$ tap water; $\mathrm{AE}=$ aerobic effluent; $\mathrm{ANE}=$ anaerobic effluent; $\mathrm{W} 1=50 \%$ of crop evapotranspiration $(\mathrm{ETc}) ; \mathrm{W} 2=100 \%$ of $\mathrm{ETc} ;$ $\mathrm{W} 3=150 \%$ of ETc; C.V. = coefficient of variation.

TABLE 6. Irrigation depth and water source for sodium content in table beet root.

\begin{tabular}{llll}
\hline & Irrigation Depth & \\
Water Source & $\mathrm{W} 1$ & $\mathrm{~W} 2$ & $\mathrm{~W} 3$ \\
\hline & Sodium $\left(\mathrm{g} \mathrm{kg}^{-1}\right)$ & & \\
$\mathrm{TW}$ & $2.00 \mathrm{Ab}$ & $1.50 \mathrm{Ac}$ & $1.68 \mathrm{Ac}$ \\
$\mathrm{AE}$ & $6.00 \mathrm{Ba}$ & $8.00 \mathrm{ABb \#}$ & $10.75 \mathrm{Ab}$ \\
$\mathrm{ANE}$ & $9.33 \mathrm{Ba}$ & $14.68 \mathrm{Aa}$ & $16.33 \mathrm{Aa}$ \\
$\mathrm{T}$ & & 2.50 & \\
\hline
\end{tabular}

C.V. $(\%) \quad 29.16$

Equivalent upper or lower case letters in rows and columns, respectively, do not differ statistically by the Tukey test (p <0.05). TW = tap water; AE = aerobic effluent; ANE = anaerobic effluent; W1 $=50 \%$ of crop evapotranspiration (ETc); W2 = 100\% of ETc; W3 = $150 \%$ of ETc; C.V. = coefficient of variation. \# Differs from the control by the Dunnett test $(\mathrm{p}<0.05)$.

TABLE 7. Macro and micronutrient contents in table beet root.

\begin{tabular}{|c|c|c|c|c|c|c|}
\hline Water Source & $\mathrm{N}$ & $\mathrm{P}$ & $\mathrm{K}$ & $\mathrm{Ca}$ & $\mathrm{Mg}$ & $\mathrm{S}$ \\
\hline$\overline{\mathrm{TW}}$ & $13.72 b$ & $1.52 \mathrm{~b}$ & $26.98 b$ & $5.02 \mathrm{a}$ & $1.63 \mathrm{bc}$ & $0.94^{\mathrm{a}}$ \\
\hline $\mathrm{AE}$ & $13.82 b$ & $1.69 \mathrm{ab}$ & $25.71 \mathrm{~b}$ & $3.81 \mathrm{c}$ & $2.01 \mathrm{ab}$ & $0.79^{\mathrm{a}}$ \\
\hline ANE & $17.57 \mathrm{a}$ & $2.02 \mathrm{a}$ & $28.14 b$ & $3.91 b c$ & $2.26 \mathrm{a}$ & $0.89^{\mathrm{a}}$ \\
\hline $\mathrm{T}$ & $16.00 \mathrm{ab}$ & $1.50 \mathrm{~b}$ & $32.62 \mathrm{a}$ & $4.57 \mathrm{ab}$ & $1.35 \mathrm{c}$ & $1.02^{\mathrm{a}}$ \\
\hline$\overline{\mathrm{C} . \mathrm{V}}$. & 15.29 & 21.16 & 11.38 & 12.04 & 20.69 & 35.71 \\
\hline \multicolumn{7}{|l|}{ Continued } \\
\hline Water Source & B & $\mathrm{Cu}$ & $\begin{array}{l}\mathrm{Fe} \\
\mathrm{kg}^{-1}\end{array}$ & $\mathrm{Mn}$ & $\mathrm{Z}$ & \\
\hline$\overline{\mathrm{TW}}$ & $19.42 \mathrm{a}$ & $13.07 \mathrm{a}$ & $345.43 a$ & $69.95 a$ & $27.68 \mathrm{a}$ & \\
\hline $\mathrm{AE}$ & $17.91 \mathrm{a}$ & $13.83 \mathrm{a}$ & $242.27 \mathrm{a}$ & $32.79 b$ & $17.62 \mathrm{a}$ & \\
\hline ANE & $19.79 \mathrm{a}$ & $16.02 \mathrm{a}$ & $239.34 a$ & $23.37 b$ & $22.24 \mathrm{a}$ & \\
\hline $\mathrm{T}$ & $23.78 \mathrm{a}$ & $13.17 \mathrm{a}$ & $381.47 \mathrm{a}$ & $79.50 \mathrm{a}$ & $27.86 \mathrm{a}$ & \\
\hline C.V. & 23.07 & 38.02 & 63.47 & 41.15 & 49.23 & \\
\hline
\end{tabular}

Matching lower case letters in the columns do not differ statistically by the Tukey test $(\mathrm{p}<0.05)$. TW $=$ tap water; $\mathrm{AE}=$ aerobic effluent; ANE = anaerobic effluent; W1 $=50 \%$ of crop evapotranspiration $(\mathrm{ETc}) ; \mathrm{W} 2=100 \%$ of ETc; W3 = 150\% of ETc; C.V. = coefficient of variation. 


\section{CONCLUSIONS}

In the soil irrigation with treated dairy effluents, the values of $\mathrm{pH}, \mathrm{P}, \mathrm{K}, \mathrm{Ca}, \mathrm{Mg}$, and $\mathrm{Na}$ increased. The micronutrients were not altered, and the high sodium contents resulted in a percentage of exchangeable sodium (PES) limit values, as recommended by the environmental agency for potential sodification.

Sodium was increased throughout the plant for effluent treatments and with increasing irrigation depths.

Leaf contents were adequate for most of the macronutrients and micronutrients in a generalized sense, including nitrogen and zinc but not phosphorus, which was reduced in effluent treatments at the smallest irrigation depth.

The different water sources influenced the contribution of $\mathrm{K}$ and $\mathrm{Ca}$ in the leaves and $\mathrm{N}, \mathrm{P}, \mathrm{K}$, $\mathrm{Ca}$, and $\mathrm{Mg}$ in the roots. Potassium, in both the leaf and root, had a behavior that was antagonistic to sodium contents, which were decreased in treatments with effluent.

The extraction of nutrients by table beet plants was adequate with the exception of phosphorus, which was only reached in the greatest irrigation depths of the anaerobic effluent treatment.

\section{ACKNOWLEDGEMENTS}

The authors would like to thank the research support foundation of São Paulo (FAPESP), $\mathrm{n}^{\circ}$ 2012/19239-0.

\section{REFERENCES}

Abegunrin TP, Awe GO, Idowu DO, Adejumobi MA (2016) Impact of wastewater irrigation on soil physico-chemical properties, growth and water use pattern of two indigenous vegetables in southwest Nigeria. Catena 139:167-178. DOI: http://dx.doi.org/10.1016/j.catena.2015.12.014

AGRIANUAL (2016) Anuário da Agricultura Brasileira. FNP, 456p.

Andrade FHA, Araújo CSP, Batista WF, Queiroga Neto JÁ, Dantas EEM, Andrade R (2016) Comportamento da cultura do pimentão submetido a diferentes níveis de salinidade. Revista Biofarm 12(3).

APHA - American Public Health Association, AWWA - American Water Works Association, WEF - Water Environment Federation (2012) Standard methods for the examination for water and wastewater. Washington, 22 ed. 1496p.

Assouline S, Narkis K (2011) Effects of long-term irrigation with treated wastewater on the hydraulic properties of a clayey soil. Water Resources Research, Washington 47:1-12. DOI: http://dx.doi.org/10.1029/2011WR010498

Ayers RS, Westcot DW (1999) A qualidade da água na agricultura. Tradução de Gheyi HR, Medeiros JF, Damasceno FAV. v29 revisado 1 (FAO). Tradução de Water quality for agriculture. Campina Grande, UFPB, 218p.

Azevedo LP, Oliveira EL (2005) Efeitos da aplicação de efluente de tratamento de esgoto na fertilidade do solo e na produtividade de pepino sob irrigação subsuperficial. Revista Brasileira de Engenharia Agrícola 25:253-263. DOI: http://dx.doi.org/10.1590/S1415-43662008000300012

Bame IB, Hughes LW, Titshall LW, Buckley CA (2014) The effect of irrigation with anaerobic baffled reactor effluent on nutrient availability, soil properties and maize growth. Agricultural Water Management 134:50-59. DOI: http://dx.doi.org/10.1016/j.agwat.2013.11.011 
Becerra-Castro C, Lopes AR, Vaz-Moreira I, Silva EF, Manaia CM, Nunes OC (2015)

Wastewater reuse in irrigation: A microbiological perspective on implications in soil fertility and human and environmental health. Environment International 75:117-135. DOI: http://dx.doi.org/10.1016/j.envint.2014.11.001

Blum J (2011) Aspectos agronômicos e ambientais da irrigação com efluente de estação de tratamento de esgoto e aplicação de fosfogesso em sistema de produção de cana de açúcar. 108f. Tese Doutorado, Escola Superior de Agricultura "Luiz de Queiroz"/USP.

Bonini MA, Sato LM, Bastos RG, Souza CF (2014) Alterações nos atributos químicos e físicos de um latossolo vermelho irrigado com água residuária e vinhaça. Revista Biociências 20:56-63.

Bourazanis G, Roussos PA, Argyrokastritis I, Kosmas C, Kerkides P (2016) Evaluation of the use of treated municipal waste water on the yield, oil quality, free fatty acids profile and nutrient levels in olive trees cv Koroneiki, in Greece. Agricultural Water Management 163:1-8. DOI: http://dx.doi.org/10.1016/j.agwat.2015.08.023

Britto DT, Kronzucker HJ (2002) $\mathrm{NH}_{4}{ }^{+}$toxicity in higher plants: a critical review. Journal of Plant Physiology 159:567-584. DOI: http://dx.doi.org/10.1078/0176-1617-0774

Burgarín MR, Baca CGA, Martínez, HJ, Tirado TJL, Martínez GA (1998). Amonio/ nitrato y concentración iônica total de La solución nutritiva en crisântemo. I. crecimiento y floración. Terra Latinoamericana 16:113-124.

Carvalho F, Prazeres AR, Rivas J (2013) Cheese whey wastewater: characterization and treatment. Science of the total environment 445-446: 385-396. DOI:

http://dx.doi.org/10.1016/j.scitotenv.2012.12.038

CETESB - Companhia de Tecnologia de Saneamento Ambiental (2006) Orientação para apresentação de projeto visando à aplicação de água de reuso proveniente de estação de tratamento de esgoto doméstico na agricultura. CETESB, $11 \mathrm{p}$.

CETESB/ANA - Companhia de Tecnologia de Saneamento Ambiental, Agencia Nacional de Águas (2011) Guia Nacional de coleta e preservação de amostras: água, sedimento, comunidades aquáticas e efluentes líquidos. CETESB, ANA, 326p.

Condé MS, Almeida Neto OB, Homem BGC, Ferreira IM, Silva MD (2013) Impact of fertirrigation with swine wastewater in an oxisol. Revista Vértices 15(2):161-178. DOI:

http://dx.doi.org/10.5935/1809-2667.20130024

Elgallal M, Fletcher L, Evans B (2016) Assessment of potential risks associated with chemicals in wastewater used for irrigation in arid and semiarid zones: A review. Agricultural Water Management 177:419-431. DOI: http://dx.doi.org/10.1016/j.agwat.2016.08.027

EMBRAPA - Empresa Brasileira de Pesquisa Agropecuária (1999) Centro Nacional e Pesquisa de Solos. Sistema brasileiro de classificação de solos. EMBRAPA, 412p.

Epstein E, Bloom AJ (2015) Mineral nutrition of plants: principles and perspectives. In: Taiz L, Zeiger E, Moller IM, Murphy A. Plant physiology and development. Sinauer Associates, 6 ed.

Erthal VJT, Ferreira PA, Pereira OG, Matos AT (2010) Características fisiológicas, nutricionais e rendimento de forrageiras fertigadas com água residuária de bovinocultura. Revista Brasileira de Engenharia Agrícola e Ambiental 14(5):458-466.

Farias JRB, Bergamaschi H, Martins SR (1994) Evapotranspiração no interior de estufas plásticas. Revista Brasileira de Agrometeorologia 2:17-22.

Ferreira DF (2011) Sisvar: A computer statistical analysis system. Ciência e Agrotecnologia 35:1039-1042. 
Ganjegunte G, Ulery A, Niu G, WU Y (2017) Effects of treated municipal wastewater irrigation on soil properties, switchgrass biomass production and quality under arid climate. Industrial crops and products 99:60-69. DOI: http://dx.doi.org/10.1016/j.indcrop.2017.01.038

Gomes TM Melfi AJ, Montes, CR, Silva E, Sundefeld Junior GC, Deon MD, Piveli RP (2009) Aporte de nutrientes e estado nutricional da cana-de-açúcar irrigada com efluente de estação de tratamento de esgoto com e sem desinfecção. Revista DAE 180:17-23.

Gomes TM, Rossi F, Tommaso G, Ribeiro R, Macan NPF, Pereia RS (2015) Treated dairy wastewater effect on the yield and quality of drip irrigated table beet. Applied Engineering in Agriculture 31(2):1-6. DOI: http://dx.doi.org/10.13031/aea.31.11002

Grundmann P, Maab O (2017) Chapter 3.2.1 - Wastewater reuse to cope with water and nutrient scarcity in agriculture - A case study for Braunschweig in Germany. Competition for water resources, p352-365. DOI: http://dx.doi.org/10.1016/B978-0-12-803237-4.00020-3

Herpin U, Gloaguen TV, Fonseca AF, Montes CR, Mendonça FC, Piveli RP, Breulmann G, Forti GMC, Melfi AJ (2007) Chemical effects on the soil-plant system in a secondary treated wastewater irrigated coffee plantation - a pilot field study in Brazil. Agricultural Water Management 89:105115. DOI: http://dx.doi.org/10.1016/j.agwat.2007.01.001

Karadag D, Köroglu OE, Ozkaya B, Cakmakci MA (2015) Review on anaerobic biofilm reactors for the treatment of dairy industry wastewater. Process Biochemistry 50(2):262-271. DOI: http://dx.doi.org/10.1016/j.procbio.2014.11.005

Leal RMP, Firme LP, Montes CR, Melfi AJ, Piedade SMS (2009) Soil exchangeable cátions, sugarcane production and nutrient uptake after wastewater irrigation. Scientia Agricola 66:242-249. DOI: http://dx.doi.org/10.1590/S0103-90162009000200014

Levy GJ, Fine P, Goldstein D, Azenkot A, Zilberman A, Chazan A, Grinhut J (2014) Long term irrigation with treated wastewater (TWW) and soil sodification. Biosystems Engineering 128:4-10. DOI: http://dx.doi.org/10.1016/j.biosystemseng.2014.05.004

Malavolta E, Vitti GC, Oliveira AS (1997) Avaliação do estado nutricional das plantas: princípios e aplicações. 2 ed. Piracicaba, Potafos, 2 ed. 319p.

Marouelli WA, Silva WLC, Silva HR (2008) Irrigação por aspersão em hortaliças: qualidade da água, aspectos do sistema e método prático de manejo. Brasília, DF, Embrapa Hortaliças, 2 ed. $150 \mathrm{p}$.

Matsumoto EM, Osako MS, Pinho SC, Tommaso G, Gomes TM, Ribeiro R (2012). Treatment of wastewater from dairy plants using Anaerobic Sequencing Batch Reactor (ASBR) following by Aerobic Sequencing Batch Reactor (SBR) aiming the removal of organic matter and nitrification. Water Practice \& Technology 7(3):1-11. DOI: http://dx.doi.org/10.2166/wpt.2012.048

Muyen Z, Moore GA, Wrigley RJ (2011) Soil salinity and sodicity effects of wastewater irrigation in South East Australia. Agricultural Water Management 99:33-41. DOI:

http://dx.doi.org/10.1016/j.agwat.2011.07.021

Nobre RG, Lima GS, Gheyi HR, Soares LAA, Silva SS, Silva AQ, Lourenço GS (2013)

Crescimento e produção da mamoneira cultivada sob diferentes níveis de salinidade da água de irrigação e doses de nitrogênio. Ciências Agrarias 34(3):961-974.

Oliveira FA, Carrilho MJS, Medeiros JF, Maracajá PB, Oliveira MKT (2011). Desempenho de cultivares de alface submetidas a diferentes níveis de salinidade da água de irrigação Performance of lettuce cultivars under different salinity levels of irrigation water. Revista Brasileira de Engenharia Agrícola e Ambiental 15(8):771-777.

Oliveira JB, Prado H (1984) Levantamento pedológico do Estado de São Paulo: quadrícula de São Carlos. II Memorial descritivo. Campinas, Instituto Agronômico de Campinas. 188p. (Boletim técnico, 98). 
Pedrero F, Allende A, Gil MI, Alarcón JJ (2012) Soil chemical properties, leaf mineral status and crop production in a lemon tree orchard irrigated with two types of wastewater. Agricultural Water Management 109:54-60. DOI: http://dx.doi.org/10.1016/j.agwat.2012.02.006

Pereira BFF, He ZL, Silva MS, Herpin U, Nogueira SF, Montes CR, Melfi AJ (2011) Reclaimed wastewater: Impacto on soil-plant system under tropical conditions. Journal of Hazardous Materials 192(1):54-61.

Prazeres AR, Carvalho F, Rivas J, Patanita M, Dôres J (2014) Reuse of pretreated cheese whey wasterwater for industrial tomato production (Lycopersicon esculentum Mill). Agricultural Water Management 140:87-95. DOI: http://dx.doi.org/10.1016/j.agwat.2014.04.002

Tivelli SW, Factor TL, Teramoto JRS, Fabri EG, Moraes ARR, Trani PE, May A (2011) Beterraba: do plantio à comercialização. Campinas, IAC. 45p. (Série Tecnológica APTA, Boletim Técnico IAC, 210).

Trani PE, Groppo GA, Silva MCP, Minami K, Burke TJ (1997) Diagnóstico sobre a produção de hortaliças no Estado de São Paulo. Horticultura Brasileira 15:19-24.

Raij BV, Cantatella H, Quaggio JÁ, Furlani AMC (1996) Recomendações de adubação e calagem para o Estado de São Paulo. Campinas, IAC, 2 ed. 285p. (Boletim técnico, 100).

Raij BV, Andrade JC, Cantarella H, Quaggio JA (2001) Análise química para avaliação da fertilidade de solos tropicais. Campinas, IAC. 285p.

Saléh BB, Campos CMM, Figuierdo JG (2009) Levantamento de parâmetros cinéticos medidos em reator anaeróbio de manta de lodo (UASB) em escala-piloto tratando efluentes de laticínio. Acta Scientiarum Technology 31:51-56. DOI: http://dx.doi.org/10.4025/actascitechnol.v31i1.823

Singh R, Gupta RK, Patil RT, Sharma RR, Asrey R, Kumar A, Jangra KK (2010) Sequential foliar application of vermicompost leachates improves marketable fruit yield and quality of strawberry (Fragaria x ananassa Duch). Scientia Horticulturae 124:34-39.

US EPA - U.S. Environmental Protection Agency (2012) Guidelines for water reuse. Washington, U.S. Agency for International Development, 642p. 